\title{
Gynecomastia Treatment with Liposuction: Clinical Experience
}

\author{
Liposuction ile Jinekomasti Tedavisi: Klinik Deneyim
}

\author{
Ali GÖKKAYA ${ }^{\mathbf{1}}$ \\ (D) 0000-0003-2710-9615 \\ Metin GÖRGÜ ${ }^{1}$ \\ (D) 0000-0001-9077-2976 \\ Burçin ACUNER \\ (D) 0000-0001-8728-279X
}

\begin{abstract}
Aim: Gynecomastia is the visible enlargement of the male breast tissue either due to physiologic, pathologic or drug-related causes. Physiological and pathological gynecomastia occurs because of the derangement of the estrogen and androgen metabolism. Drug-related gynecomastia is seen when using drugs affecting this hormone metabolism as well as a side effect of different drugs. Successful treatment of gynecomastia was reported with medical treatment and cessation of the possible causative drugs especially in early period, and with direct excision, endoscopic subcutaneous mastectomy and excision with liposuction treatments in the late period.

Material and Methods: In this study, we reported our results of gynecomastia treatment with suction assisted wet liposuction in 3 different planes using 3 different thickness cannulas in Grade I, II and III patients. Forty five patients were operated between 2009 and 2019 using this technique in our clinique. All patients were followed for up to a minimum of 6 months to observe the complication rate and the final aesthetic result.

Results: Within the 45 patients evaluated in this study, the complication rate was $6.7 \%$, the success rate of the operation was $93.3 \%$ and the patient satisfaction was $91.1 \%$. Gynecomastia treatment in general -especially liposuction- was reviewed and our results were evaluated based on the literature results.

Conclusion: There are many different options for gynecomastia treatment. In this study, we concluded that in Grade I, II, and III patients good results can be achieved and patient satisfaction is high in gynecomastia treatment with wet liposuction.

Keywords: Endocrine breast diseases; gynecomastia; liposuction; body contouring
\end{abstract}

\section{ÖZ}

Amaç: Jinekomasti fizyolojik, patolojik veya ilaca bağlı nedenlerle erkeklerdeki normal meme dokusunun görünür hale gelecek kadar büyümesidir. Fizyolojik ve patolojik jinekomasti östrojen ile androjen metabolizmasındaki bozulmadan dolayı ortaya çıkmaktadır. İlaca bağlı jinekomasti ise yine bu hormonal metabolizmayı etkileyen hormonlar dışında farklı ilaç gruplarında da yan etki olarak görülebilmektedir. Jinekomasti tedavisinde özellikle erken dönemde medikal tedavi ve neden olabilecek ilaçların kesilmesi, daha ileri dönemlerde ise direkt eksizyon, endoskopik subkutan mastektomi, liposuction yöntemleri ile eksizyon gibi çeşitli yöntemlerle başarılı sonuçlar bildirilmiştir.

Gereç ve Yöntemler: Bu çalışmada Evre I, II ve III hastalarda 3 farklı planda 3 farklı kalınlıkta kanüller ile aspirasyon destekli islak liposuction (suction assisted wet liposuction) tekniği ile jinekomasti tedavi sonuçlarımızı sunmaktayız. Bu teknik ile kliniğimizde 2009 ile 2019 arasında 45 hasta opere edilmiştir. Tüm hastalar operasyon sonrasında komplikasyon oranlarının ve nihai estetik sonucun gözlemlenebilmesi için postoperatif dönemde en az 6 ay takip edilmiştir.

Bulgular: $\mathrm{Bu}$ çalışmada değerlendirilen 45 hastada komplikasyon oranı \%6,7, operasyon başarı oranı \% $\% 33,3$ ve hasta memnuniyeti \%91,1 idi. Jinekomasti tedavisinde başta liposuction olmak üzere diğer mevcut tedaviler gözden geçirilmiş ve çalıșmamızdaki sonuçlar literatür eşliğinde değerlendirilmiştir.

Sonuç: Jinekomastinin cerrahi tedavisinde mevcut çok sayıda farklı yöntem bulunmaktadır. $\mathrm{Bu}$ çalışmada ıslak liposuction yöntemi ile jinekomasti tedavisinde Evre I, II ve III hasta grubunda başarılı sonuçlar elde edildiği ve hasta memnuniyetinin yüksek olduğu gösterilmiştir.

Received / Geliş Tarihi : 03.12.2019 Accepted / Kabul Tarihi : 09.03.2020 Available Online / Çevrimiçi Yayın Tarihi : 25.04.2020
Presented as an abstract at $40^{\text {th }}$ National Congress of Turkish Society of Plastic Reconstructive and

Anahtar kelimeler: Endokrin meme hastalıkları; jinekomasti; liposuction; vücut şekillendirme Aesthetic Surgery, (October 17-21, 2018, Antalya, Turkey) 


\section{INTRODUCTION}

Male breast tissue is composed of small amount of ductal and stromal tissue instead of the glandular tissue found in female breast (1). Gynecomastia is the benign proliferation of these ductal and stromal tissues due to derangement of estrogen/androgen balance (2,3). This proliferation subsequently increases the visibility of normally invisible male breast tissue (4). The incidence of gynecomastia is reported as $32-70 \%$ in the literature, and $50 \%$ of cases occur bilaterally $(1,5,6)$. In Turkey, Neyzi et al. (7) reported this incidence as $7 \%$ between ages 9 to 17 whereas Güvenç et al. (8) reported as $19.6 \%$ unilaterally and $34.6 \%$ bilaterally. There is no identifiable etiologic cause in $25 \%$ of gynecomastia cases and the remaining possible causes may be classified as physiological, pathological or drug-related (6). Derangement of hormonal balance in favor of estrogen may cause physiological or pathological gynecomastia $(4,6)$. Common gynecomastia causes are listed in Table $1(3,5,9)$. There are six different types of grading systems for gynecomastia. In Table 2, the three most commonly preferred grading systems -Cordova-Moschella, Rochrich, Simon- are listed (9-11). In our clinic, we prefer to use the Simon Classification as it is simple and practical (Table 2). Gynecomastia treatment is planned according to the grade of the disease, the nature of the breast tissue and the duration of symptoms. Even though the disease may regress especially in adolescents, treatment may be necessary as it causes pain and tenderness along with

Table 1. Causes of gynecomastia $(3,5,9)$

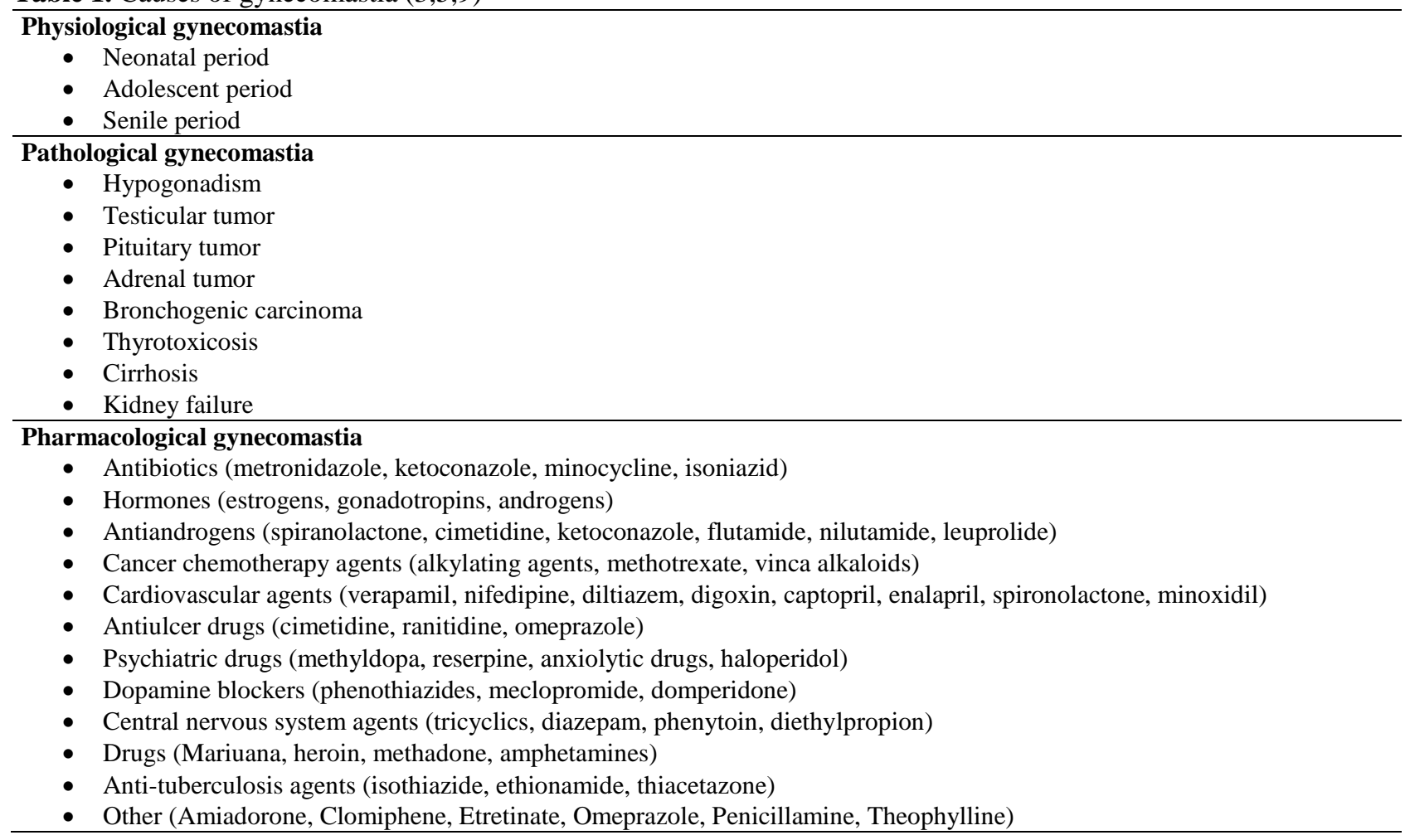

Table 2. Comparison of different classifications of gynecomastia

\begin{tabular}{|c|c|c|}
\hline \multirow{5}{*}{$\begin{array}{l}\text { Cordova-Moschella } \\
\text { (2006) (10) }\end{array}$} & Grade I & Increase in diameter and protrusion limited to the areolar region \\
\hline & Grade II & $\begin{array}{l}\text { Hypertrophy of all the structural components of the breast } \\
\text { The nipple-areola complex is above the inframammary fold }\end{array}$ \\
\hline & Grade III & Hypertrophy of all the structural components \\
\hline & Grade ili & Nipple-areola complex at the same height as or about $1 \mathrm{~cm}$ below the inframammary fold \\
\hline & Grade IV & $\begin{array}{l}\text { Hypertrophy of all the structural components } \\
\text { Nipple-areola complex more than } 1 \mathrm{~cm} \text { below the inframammary fold }\end{array}$ \\
\hline \multirow{4}{*}{$\begin{array}{l}\text { Rochrich } \\
(\mathbf{2 0 0 3})(9)\end{array}$} & Grade I & Minimal hypertrophy $(<250 \mathrm{~g})$ without ptosis, Primary glandular, Primary fibrous \\
\hline & Grade II & Moderate hypertrophy (250-500 g) without ptosis, Primary glandular, Primary fibrous \\
\hline & Grade III & Severe hypertrophy (>500 g), Grade I ptosis \\
\hline & Grade IV & Severe hypertrophy ( $>500 \mathrm{~g}$ ), Grade II or III ptosis \\
\hline \multirow{4}{*}{$\begin{array}{l}\text { Simon } \\
\text { (1973) (11) }\end{array}$} & Grade I & Minor enlargement, no redundant skin \\
\hline & Grade IIa & Moderate enlargement, no redundant skin \\
\hline & Grade IIb & Moderate enlargement with minor skin redundancy \\
\hline & Grade III & Gross breast enlargement with marked skin redundancy \\
\hline
\end{tabular}


psychological symptoms (6). The treatment may be planned as medically or surgically regarding the grade of the disease. Surgical treatment modalities are classified as liposuction or excisional methods chosen on patient characteristics (12). The effective results of these various treatment modalities in different patient groups are well documented in the literature (9,13-15). In this study, we present the results of our treatment method as liposuction using varying thickness cannulas in different tissue planes alone or with short scar excision in Simon Grade I, II and III patients (Figure 1). The advantages and disadvantages of this technique are discussed along with the relevant literature.

\section{MATERIAL AND METHODS}

Between 2009 and 2019, 45 gynecomastia patients were operated by liposuction +/- short scar excision in the Department of Plastic Reconstructive and Aesthetic Surgery at Abant İzzet Baysal University. The study was approved by Bolu Abant İzzet Baysal University Clinical Researches Ethics Committee by the number 2019/300 and dated 19.12.2019. Written informed consent was obtained from all patients. Thirty-eight of the patients were primary and seven had previously been operated in other centers and presented with unsatisfactory results. Eight of the 38 patients were evaluated as Grade I, twenty-six as Grade II, and four as Grade III (Figure 1). Fat volume obtained by liposuction was calculated as minimum $100 \mathrm{cc}$ and maximum $1000 \mathrm{cc}$ from the total of two breasts and the mean was $540 \mathrm{cc}$. The results were evaluated by photographs of the patients by 3 surgeons; averaged and classified as inadequate, good, and excellent. When all three surgeons reached a different result, they were asked to re-evaluate. The patients were also asked to evaluate their satisfaction as inadequate, good, and excellent.

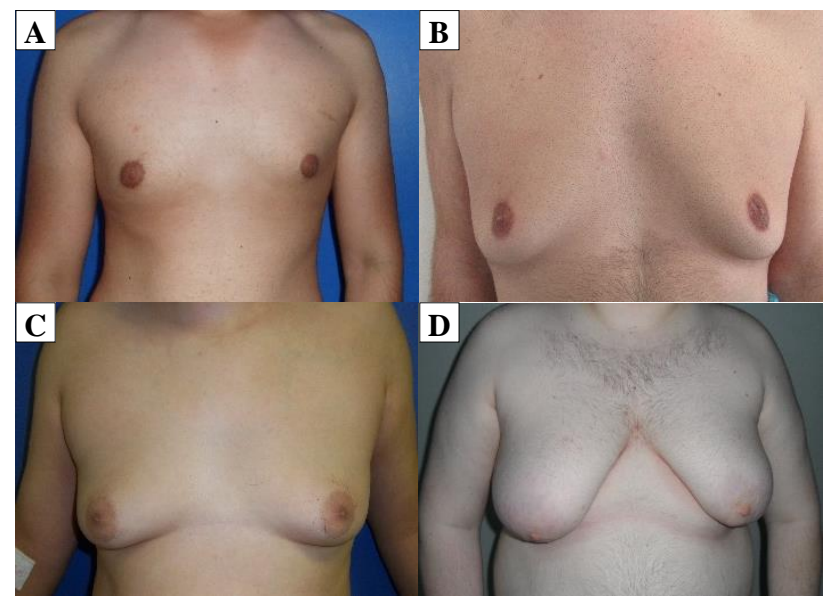

Figure 1. Gynecomastia patients from our clinic, Simon A) Grade I, B) Grade IIa, C) Grade IIb and D) Grade III

Table 3. Postoperative results (minimum of 6 months)

\begin{tabular}{lcc}
\hline & Surgeon evaluation & Patients' evaluation \\
\hline Inadequate & $3(6.7 \%)$ & $4(8.9 \%)$ \\
\hline Good & $7(15.5 \%)$ & $13(28.9 \%)$ \\
\hline Excellent & $35(77.8 \%)$ & $28(62.2 \%)$ \\
\hline
\end{tabular}

\section{Surgical Technique}

The operation can be performed under local, sedation or general anesthesia. The patient's planning is done before the operation while the patient is standing. For wet technique, liposuction solution is prepared by adding $1000 \mathrm{cc}$ ringer lactate $+2 \%$ lidocaine $+1: 1000$ epinephrine. The solution is then injected into the preoperatively marked region (Figure 2A). For liposuction, two incisions are made for the cannula entry with 11 blade, one on the edge of the nipple and the other on the lateral side of the breast; additional incisions can be made if necessary. Ten minutes after the injection, liposuction is performed first to the deep region with $4 \mathrm{~mm}$ cannula, then to the superficial layer with $3 \mathrm{~mm}$ cannula and to the subareolar region with $2 \mathrm{~mm}$ cannula (Figure 2B, C, D, E). At the end of the operation, if the gland remains under the nipple, the liposuction incision at the border of the nipple is expanded to $1 \mathrm{~cm}$ and the gland is easily excised from here (Figure 2F). After sutures are placed on the incisions, dressing is performed and moderate pressure is applied to the thorax with elastic bandage. All patients were mobilized early in the postoperative period and postoperative drains were not used.

\section{RESULTS}

Seroma was seen in 2 patients as early complication and late complication was not seen except inadequate result. Results were excellent in 35 patients, good in 7 patients, and inadequate in 3 patients (Figures 3, 4, 5 and 6). In the evaluation, $93.3 \%$ of the surgical results were found to be successful. Three patients who were found to be inadequate underwent revision; in two of these patients who had Grade III gynecomastia preoperatively, minor periareolar skin excision was added, and in one patient the skin retraction was corrected surgically. The patient satisfaction rate was $91.1 \%$. The results are summarized in Table 3.

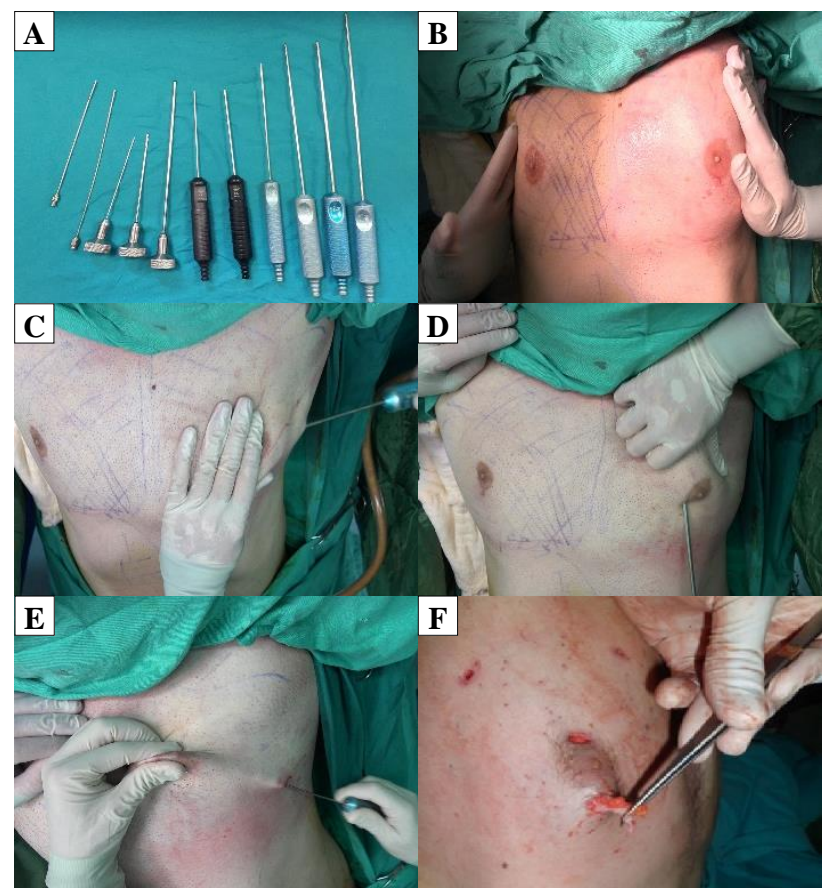

Figure 2. Operation technique A) Liposuction cannulas 2, 3, $4 \mathrm{~mm}$; B) Inflating breast tissue with solution, wet technique; C-E) Liposuction procedure with 3 different cannulas in 3 different planes; F) Excision of the remaining glandular tissue by extending the periareolar incision to $1 \mathrm{~cm}$ 


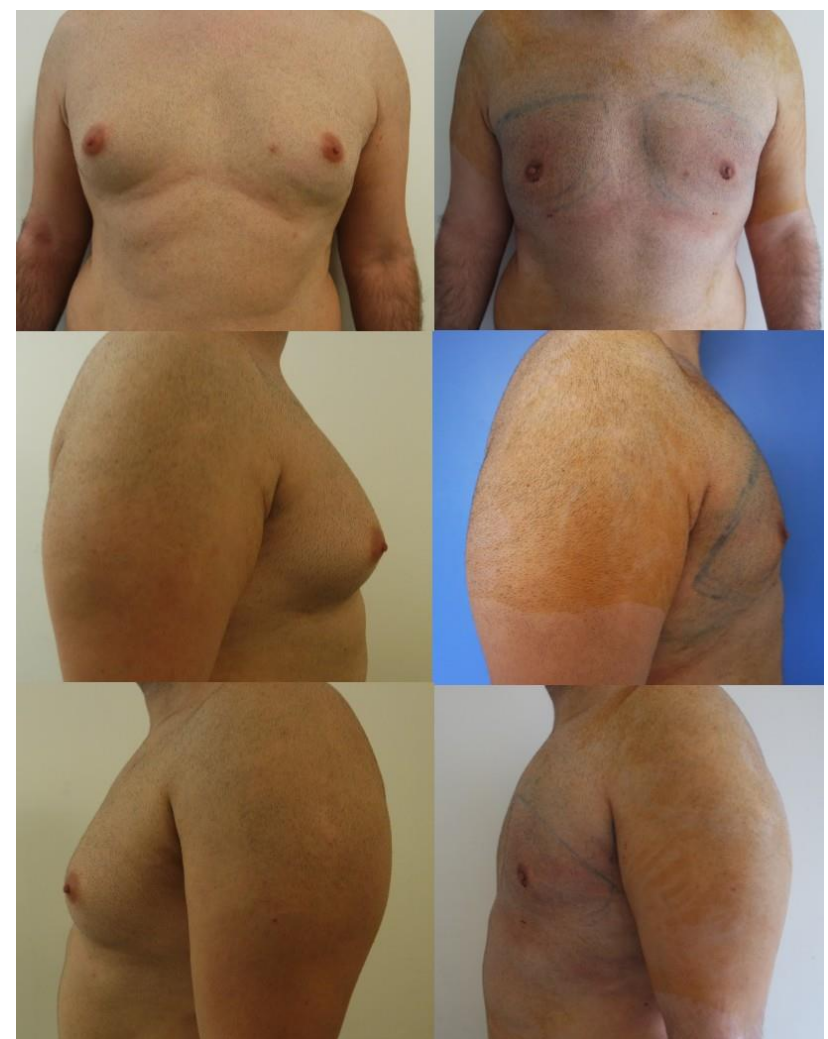

Figure 3. Gynecomastia patient, preoperative and 1 day postoperative images

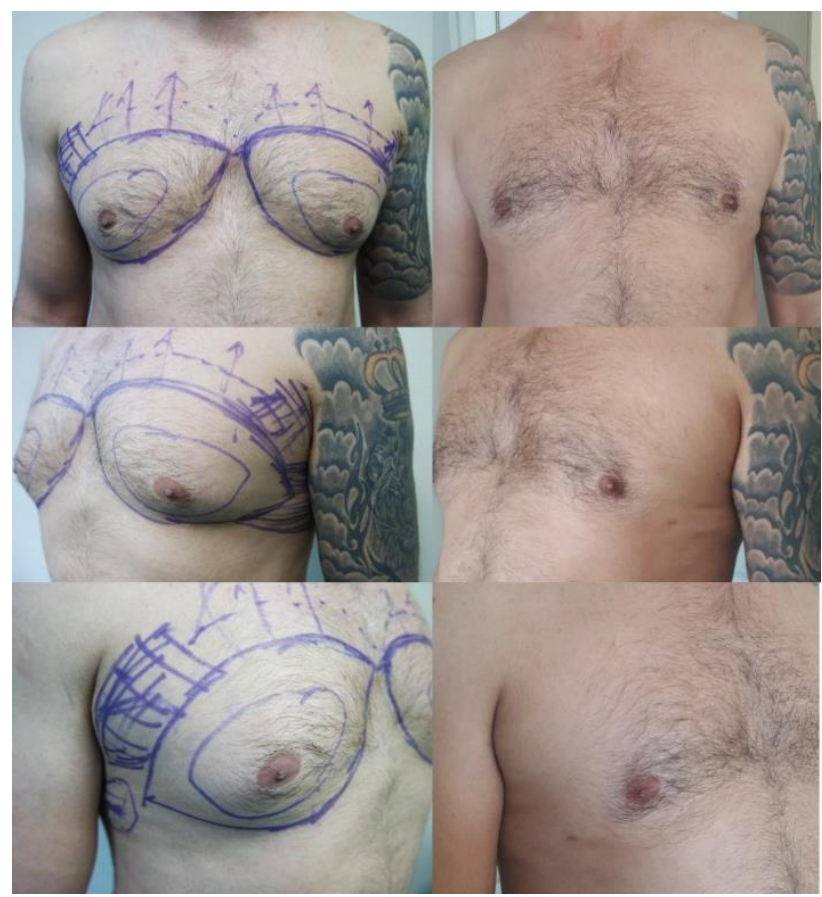

Figure 4. Gynecomastia patient, preoperative and 6 months postoperative images

\section{DISCUSSION}

Gynecomastia is the increased visibility of breast tissue that normally exists in men, after benign proliferation due to physiological, pathological or drug-related reasons (12). Physiological gynecomastia is seen in neonates, adolescents, and the elderly. Gynecomastia in the newborn

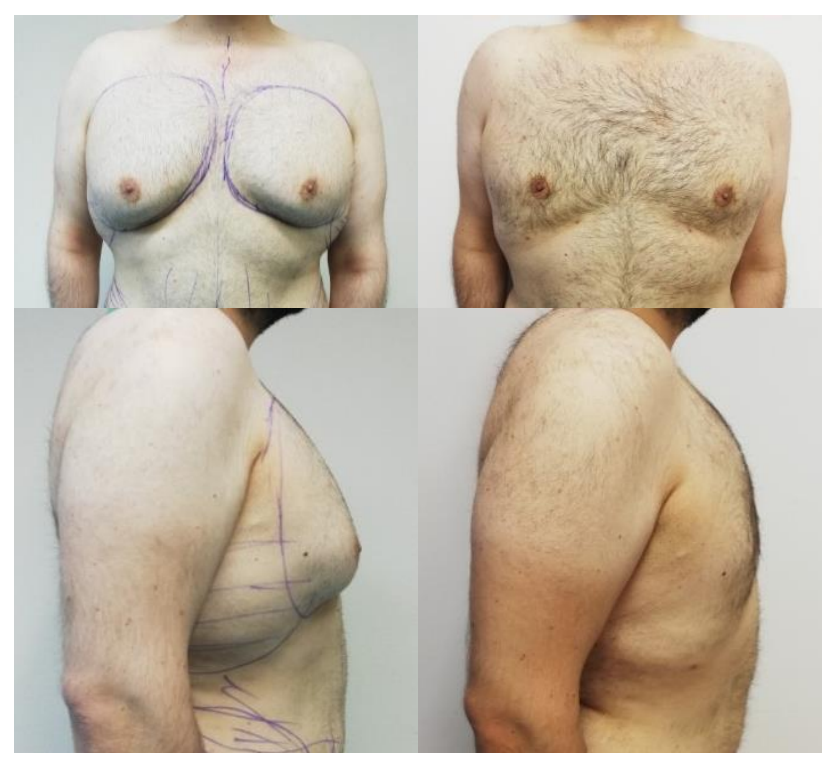

Figure 5. Gynecomastia patient, preoperative and 1 year postoperative images

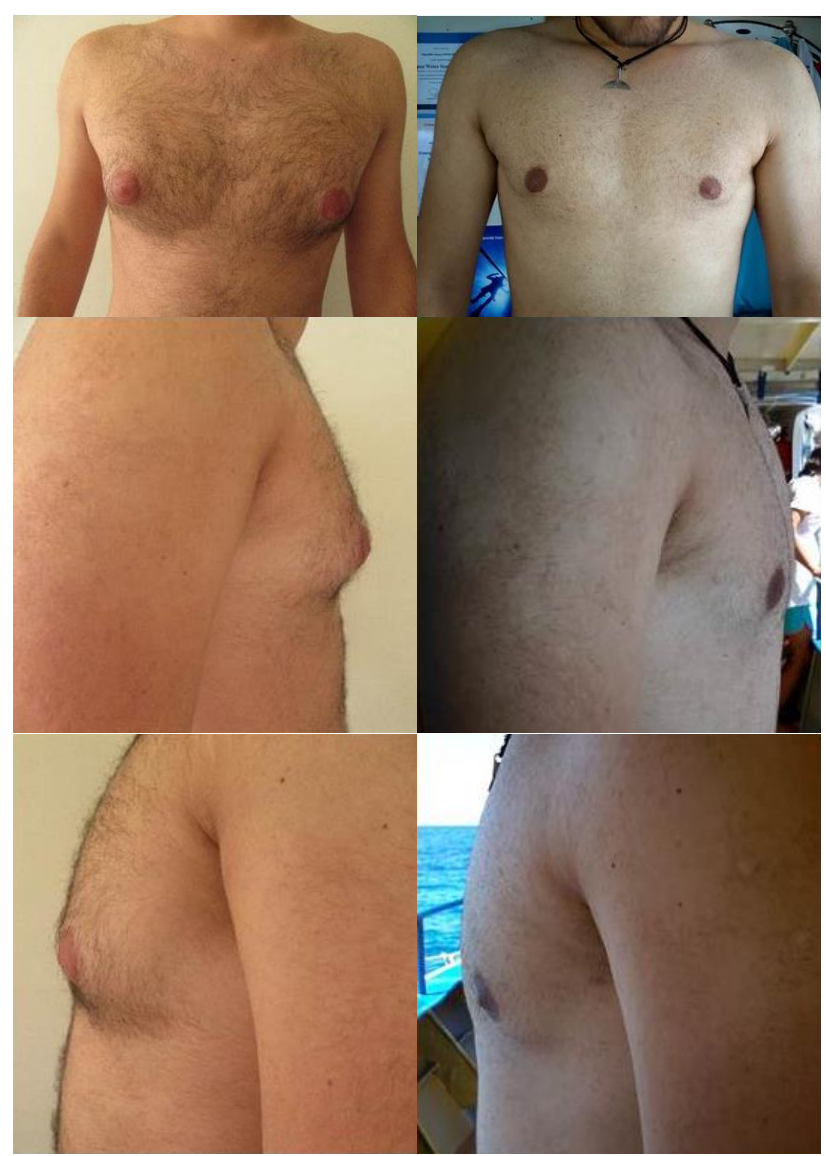

Figure 6. Revision gynecomastia patient, pre-revision and 9 months postoperative images

regresses within one year at the latest, while gynecomastia seen in adolescence and old age becomes fibrotic and permanent, especially when it exceeds a year (3).

When the patient is admitted to the outpatient clinic due to gynecomastia, the drugs used by the patient should be 
questioned, the presence of real gynecomastia should be confirmed by physical examination and imaging methods, hormone profile should be requested and physical examination must include testicular examination (6). Physical examination may reveal an increase in the areola diameter, a deterioration of the thorax profile due to breast enlargement, abnormal localization of the inframmamarian fold, ptosis and asymmetry where nipple areolar complex may fall to the fold level or inferior (10). While the causes of gynecomastia are excluded, it should be kept in mind that men may also have breast cancer and this possibility should be ruled out (5). The growth in male breast cancer is usually unilateral and is found as a hard and painless mass anywhere in the breast. In addition, there are signs such as retraction on the skin or nipple and discharge from the nipple. Biopsy can be performed from the mass if necessary to exclude cancer (9).

\section{Treatment Options}

The aim of gynecomastia treatment is to achieve normal body image with minimal surgical scar as well as pain relief (16). During the adolescent period, gynecomastia occurs in different degrees, which regressed within a few months to years. In this period, the pathogenesis of gynecomastia is related to high plasma estradiol compared to testosterone $(2,17)$. Gynecomastia in adolescents should not be operated until 3 years have passed and it is decided that spontaneous regression is no longer possible (2). Although gynecomastia seen in adolescence may regress spontaneously, treatment should be planned considering the psychological effect of the condition (16). Especially in adolescent gynecomastia, if accompanied by obesity, the existing fat tissue will increase the prominence of gynecomastia, weight loss should also be recommended in these circumstances (16). In addition, in case of obesity, pseudogynecomastia may also be seen with increased adipose tissue in the breast (5). Clinically, it is possible to obtain information about the nature of the breast tissue by palpation and ultrasonography examination (6). In gynecomastia seen in adults, operation is indicated if gynecomastia continues for more than a year or one year after the underlying cause has been corrected (6).

\section{Medical Treatment}

In medical treatment, especially in adolescent gynecomastia, drugs such as tamoxifene, raloxifene, clomiphene that block specific estrogen effects in mammary tissue with serum estrogen receptor modulator effects, danazol which has the effect of androgen receptor agonist, and anastrazole or testolactone which inhibit estrogen production can be tried $(2,5,6,18,19)$. It has been shown that these medications reduce pain associated with gynecomastia but provide a minimal reduction in gynecomastia size (18). In addition, if gynecomastia persists for more than a year, medical treatment will not be effective because the breast tissue becomes fibrotic $(6,20)$.

\section{Surgical Treatment}

The aim of surgical treatment for gynecomastia is to make the chest area aesthetically pleasing and while achieving this goal, to hide the surgical scar as much as possible, to protect the nipple sensation and to minimize skin irregularities (15). Current surgical treatment options include minimally invasive methods, surgical excision, or both (21). Skin excision can also be planned depending on whether the skin is excessive or not (16). Surgical treatment can be performed under local anesthesia with sedation, under local anesthesia alone or under general anesthesia (20). Open surgical excision techniques using semicircular periareolar incision have high morbidity (22). Minimally invasive methods include suction assisted liposuction, power assisted liposuction, ultrasound assisted liposuction, laser assisted liposuction and vacuum assisted minimally invasive or endoscopic subcutaneous mastectomy $(2,22,23)$. Suction assisted liposuction may sometimes not be sufficient alone, because the male breast structure contains more fibrous septum than female breast tissue (11). Ultrasound assisted liposuction and power assisted liposuction are more effective in the treatment of gynecomastia than conventional suction assisted liposuction. When the ultrasonic method is applied to the subdermal plan close to the skin, it may provide retraction of the excess skin, but the major disadvantage is the possibility of thermal damage to the surrounding skin $(2,11)$. In a systematic review by Fagerlund et al. (5), surgical excision combined with liposuction was reported to be the most permanent outcome and the least complication rate. Abdelrahman et al. (20) reported that they achieved acceptable results in $92 \%$ of patients with Grade I and II gynecomastia after suction assisted liposuction with fat-disrupting cannulas. In our clinical series, we achieved similar success rates in the literature in patients who underwent liposuction alone or minimal subareolar gland removal when necessary. Devices used in ultrasonic (Vaser), laser and other assisted liposuction techniques are expensive and not available in all clinics. The advantages of the presence of such devices cannot be denied, but the costs cannot be covered by every patient. It is possible to achieve successful results with classical wet liposuction technique by using rigorous working technique and by using different thickness cannulas at different stages of the procedure. There is a local anesthetic in the fluid given for liposuction, so local anesthesia under sedation will be sufficient for the majority of patients. This is the most commonly used method in our experience. While the patient is in deep sedation, fluid injection is completed in 10-15 minutes, and then the operation is completed with local anesthesia in 45-90 minutes.

The most common complications reported in the literature after surgical treatment of gynecomastia are hematoma in early period and inadequate excision in late period. In addition to these, early complications include ecchymosis, fat necrosis and seroma, infection, deep vein thrombosis, pulmonary embolism, and late complications include deformities of the nipple areolar complex like inverted nipple $(11,15,18)$. In a study by Zavlin et al. (21), the rate of surgical complications in 204 pediatric and 1583 adult gynecomastia patients was reported to be $3.9 \%$ and $1.9 \%$ respectively. Fagerlund et al. (5) reported a postoperative complication rate of up to $20 \%$ in different surgical techniques. In our series, seroma was seen in 3 patients $(6.7 \%)$ as early complications and inadequate excision in 3 patients $(6.7 \%)$ as late complications. This is a low complication rate compared to the reported rate in the literature.

Vacuum lipoplasty (vacuumroller LPG massage) or ultrasound-guided lipoplasty (ultrasonic cavitation devices) can be used to shape the remaining tissues and skin excess after liposuction treatment of gynecomastia 
(10). Cryolipolysis and radiofrequency treatments can be used primarily in patients with pseudogynecomastia as well as shaping the remaining tissue after surgical treatment (18).

\section{CONCLUSION}

In the treatment of gynecomastia, different methods are recommended according to the duration of the disease, the etiological cause, the amount and characteristics of the available breast tissue, the presence of excess skin, and the location of nipple areolar complex. The fact that there are so many factors affecting the choice and success of treatment makes it difficult to apply a standard management in every gynecomastia patient. Classical wet liposuction technique yielded good reproducible results in our patients with Grade I, II and III gynecomastia; with a success rate of $93 \%$ and patient satisfaction rate of $91.1 \%$. The advantages of the technique are short hospitalization, return to normal life in the early period, low complication rate, low cost and aesthetically acceptable results. For this reason, liposuction method applied to different tissue planes with different thickness cannulas is a preferable treatment method in the treatment of patients with Grade I, II and III gynecomastia. Gynecomastia is treated with low complication rates and highly satisfactory results with standard liposuction techniques.

\section{REFERENCES}

1. Blau M, Hazani R, Hekmat D. Anatomy of the gynecomastia tissue and its clinical significance. Plast Reconstr Surg Glob Open. 2016;4(8):e854.

2. Soliman AT, De Sanctis V, Yassin M. Management of adolescent gynecomastia: an update. Acta Biomed. 2017;88(2):204-13.

3. Kanakis GA, Nordkap L, Bang AK, Calogero AE, Bártfai G, Corona G, et al. EAA clinical practice guidelines-gynecomastia evaluation and management. Andrology. 2019;7(6):778-93.

4. Rasko YM, Rosen C, Ngaage LM, AlFadil S, Elegbede $\mathrm{A}$, Ihenatu $\mathrm{C}$, et al. Surgical management of gynecomastia: a review of the current insurance coverage criteria. Plast Reconstr Surg. 2019;143(5):1361-8.

5. Fagerlund A, Lewin R, Rufolo G, Elander A, Santanelli di Pompeo F, Selvaggi G. Gynecomastia: a systematic review. J Plast Surg Hand Surg. 2015;49(6):311-8.

6. Baumann K. Gynecomastia - conservative and surgical management. Breast Care (Basel). 2018;13(6):419-24.

7. Neyzi O, Alp H, Yalcindag A, Yakacikli S, Orphon A. Sexual maturation in Turkish boys. Ann Hum Biol. 1975;2(3):251-9.

8. Güvenç H, Yurdakök M, Kinik E, Büyükgebiz A. The incidence of pubertal gynecomastia in boys living in the Ankara region. Turk J Pediatr. 1989;31(2):123-6.
9. Bailey SH, Guenther D, Constantine F, Rohrich RJ. Gynecomastia management: an evolution and refinement in technique at UT Southwestern Medical Center. Plast Reconstr Surg Glob Open. 2016;4(6):e734.

10. Cordova A, Moschella F. Algorithm for clinical evaluation and surgical treatment of gynaecomastia. J Plast Reconstr Aesthet Surg. 2008;61(1):41-9.

11. Lee YK, Lee JH, Kang SY. Gynecomastia: glandularliposculpture through a single transaxillary one hole incision. J Plast Surg Hand Surg. 2018;52(2):117-25.

12. Brown RH, Chang DK, Siy R, Friedman J. Trends in the surgical correction of gynecomastia. Semin Plast Surg. 2015;29(2):122-30.

13. Jin Y, Fan M. Treatment of gynecomastia with prednisone: case report and literature review. J Int Med Res. 2019;47(5):2288-95.

14. Collins PS, Moyer KE. Evidence-based practice in liposuction. Ann Plast Surg. 2018;80(6S Suppl 6):S403-5.

15. Khalil AA, Ibrahim A, Afifi AM. No-drain single incision liposuction pull-through technique for gynecomastia. Aesthetic Plast Surg. 2017;41(2):298303.

16. Hammond DC. Surgical correction of gynecomastia. Plast Reconstr Surg. 2009;124(1 Suppl):61e-8e.

17. Ibrahiem SM. Severe gynecomastia: new technique using superior pedicle NAC flap through a circumareolar approach. Ann Plast Surg. 2016;76(6):645-51.

18. Munavalli GS, Panchaprateep R. Cryolipolysis for targeted fat reduction and improved appearance of the enlarged male breast. Dermatol Surg. 2015;41(9):1043-51.

19. Fischer S, Hirsch T, Hirche C, Kiefer J, Kueckelhaus M, Germann G, et al. Surgical treatment of primary gynecomastia in children and adolescents. Pediatr Surg Int. 2014;30(6):641-7.

20. Abdelrahman I, Steinvall I, Mossaad B, Sjoberg F, Elmasry M. Evaluation of glandular liposculpture as a single treatment for grades I and II gynaecomastia. Aesthetic Plast Surg. 2018;42(5):1222-30.

21. Zavlin D, Jubbal KT, Friedman JD, Echo A. Complications and outcomes after gynecomastia surgery: analysis of 204 pediatric and 1583 adult cases from a national multi-center database. Aesthetic Plast Surg. 2017;41(4):761-7.

22. Varlet F, Raia-Barjat T, Bustangi N, Vermersch S, Scalabre A. Treatment of gynecomastia by endoscopic subcutaneous mastectomy in adolescents. J Laparoendosc Adv Surg Tech A. 2019;29(8):1073-6.

23. Yao Y, Yang Y, Liu J, Wang Y, Zhao Y. Vacuumassisted minimally invasive surgery-An innovative method for the operative treatment of gynecomastia. Surgery. 2019;166(5):934-9. 